\title{
Genus Phoma according to the newest taxonomic changes
}

\section{Rodzaj Phoma w świetle najnowszych zmian taksonomicznych}

\author{
Joanna Marcinkowska*
}

\section{Summary}

Genus Phoma was described by Saccardo in Sphaeropsidales, Fungi Imperfecti. Species of this genera were characterized by hyaline, 1-celled conidia produced in pycnidia on stems and twigs of plants. For years species of Phoma were identified based on morphological characters studied earlier only in vivo but later also in vitro on 3 standard media. Because of morphological diversity of species identified as Phoma by the end of the 20. century taxonomists divided this genera into 9 sections. Carried out phylogenetic studies of species typical of all sections revealed that they belonged to order Pleosporales, but to 3 different families. It was found that the number of genera distinguished recently from Phoma was higher than the number of sections described earlier. Based on phylogeny and morphological characters of species belonging earlier to the sections of Phoma new genera were distinguished and characterized. Among them are taxons described for the first time, e.g. Boeremia, and genera for which names were given earlier, e.g. Plenodomus (renamed one) as well as Phoma sensu stricto. Key and descriptions of these genera have been provided.

Key words: Phoma sensu lato; key to genera; characters of genera

\section{Streszczenie}

Saccardo przyporządkował rodzaj Phoma do Sphaeropsidales w Fungi Imperfecti. Jego gatunki charakteryzowały się wytwarzaniem hialinowych, jednokomórkowych zarodników konidialnych, które tworzyły się w piknidiach na pędach lub gałązkach roślin. Przez dziesiątki lat opisywano gatunki Phoma na podstawie cech morfologicznych badanych początkowo tylko in vivo, a następnie także in vitro na 3 standardowych pożywkach. Zróżnicowanie morfologiczne gatunków Phoma doprowadziło do wyróżnienia 9 sekcji w tym rodzaju. Przeprowadzone wkrótce badania filogenetyczne gatunków typowych wszystkich sekcji wykazały, że należały one do rzędu Pleosporales, ale do 3 różnych rodzin. Wykazano, że liczba rodzajów wyróżnionych ostatnio z Phoma przewyższa liczbę opisanych wcześniej sekcji. Na podstawie właściwości filogenetycznych i cech morfologicznych gatunków zaliczonych wcześniej do wszystkich sekcji rodzaju Phoma scharakteryzowano nowo wyłonione rodzaje. Wśród nich są taksony opisane pierwszy raz, np. Boeremia oraz rodzaje, dla których przywrócono wcześniejsze ich nazwy, np. Plenodomus, a także Phoma sensu stricto. Zamieszczono klucz do rodzajów i ich charakterystykę.

Słowa kluczowe: Phoma sensu lato; klucz do rodzajów; charakterystyka rodzajów 


\section{Wstęp / Introduction}

Badania literatury taksonomicznej grzybów anamorficznych kilku ostatnich lat wykazały, że najbardziej znaczące zmiany odnośnie charakterystyki rodzaju, a przy tym przynależności do niego różnych gatunków dotyczą Phoma (Gruyter 2012). Po raz pierwszy rodzaj Phoma opisany został przez Saccardo w 1880 roku, wówczas jako jeden z Fungi Imperfecti zaliczanych do Sphaeropsidales. Zdaniem Saccardo (1880) gatunki należące do Phoma charakteryzowały się wytwarzaniem hialinowych, jednokomórkowych zarodników konidialnych - konidiów nazywanych też piknosporami w piknidiach, które tworzyły się na pędach lub gałązkach. Jeśli gatunki tworzyły hialinowe, jednokomórkowe konidia w piknidiach na liściach zaliczano je do rodzaju Phyllosticta, a gdy konidia w piknidiach na liściach były dwukomórkowe to należały do rodzaju Ascochyta (Marcinkowska 2003).

Uwzględniając obserwowane in vivo cechy morfologiczne konidiów i piknidiów oraz organ rośliny, na którym tworzyły się te ostatnie, opisywano przez szereg lat coraz to nowe (ponad 2000) gatunki Phoma i pokrewnych rodzajów (Marcinkowska 2003).

Ogromna liczba gatunków i zamieszanie przy ich oznaczaniu doprowadziły do rozpoczęcia intensywnych badań nad taksonomią Phoma, zwłaszcza gatunków patogenicznych dla roślin (Boerema 1964). Założeniem systemu Boerema i wsp. (1981) było określenie taksonu na podstawie cech morfologicznych obserwowanych nie tylko jak dotychczas in vivo, ale także i in vitro, jako stałych, w kulturach rozwijających się w standardowych warunkach na trzech pożywkach agarowych: OA (owsianej), MA (maltozowej) i CA (czereśniowej).

Liczba opisanych gatunków została znacznie zredukowana, do około 200, ale ich duże zróżnicowanie morfologiczne spowodowało podział rodzaju Phoma na sekcje (Boerema 1993, 1997). Wówczas opracowano monografie (contributions) rodzaju Phoma. Każda z nich dotyczyła zazwyczaj danej sekcji, zawierała klucze do oznaczania gatunków, ich opisy oraz indeksy roślin gospodarzy i gatunków grzybów (Boerema 1993; Boerema i wsp. 1994; Aa i wsp. 2000; Gruyter i Boerema 2002; Gruyter i wsp. 2002). Wyniki tych wieloletnich badań gatunków Phoma zostały przedstawione $\mathrm{w}$ podręczniku dotyczącym ich identyfikacji (Boerema i wsp. 2004). W Polsce zanotowano powyżej 150 gatunków i odmian botanicznych Phoma sensu lato (Mułenko i wsp. 2008).

Prowadzone równocześnie w ostatnich dziesiątkach 20. wieku badania nad systematyką grzybów doprowadziły do odrzucenia sztucznego, saccardowskiego, hierarchicznego (klasy, rzędy, rodziny) podziału Fungi Imperfecti na taksony (Kirk i wsp. 2001). Bezpłciowo rozmnażające się grzyby (Fungi Imperfecti) stanowiące stadia konidialne nazywane też grzybami anamorficznymi podzielono na 3 formy morfologiczne (grupy), dla których przyjęto nazwy dawnych sztucznych klas wyróżnianych w Fungi Imperfecti. Do scharakteryzowania rodzajów grzybów rozmnażających się bezpłciowo taksonomowie opracowali system kodowy, w którym, poza typem konidiomy, scharakteryzowali morfologię i sposób powstawania konidiów (Marcinkowska 2003). Rodzaj Phoma cechuje się kodem: Cpd.0-1eH.15 (Kirk i wsp. 2008), który oznacza, że jego gatunki tworzą piknidia (Cpd.), ich konidia są 1-2 komórkowe (0-1), elipsoidalne (e), hialinowe (H) i powstają enteroblastycznie na fialidach (15).

Wkrótce jednak opracowany przez Holendrów system dzielący rodzaj Phoma na sekcje (Boerema i wsp. 2004) wydał się jego autorom nieco sztuczny toteż wykonali badania, które spowodowały konieczność reklasyfikacji Phoma.

Celem tej publikacji było opracowanie w języku polskim zmian dotyczących taksonomii rodzaju Phoma na podstawie literatury $\mathrm{z}$ ostatnich lat.

\section{Wyniki i dyskusja / Results and discussion}

Torres i wsp. (2005) stwierdzili, że gatunki sekcji Plenodomus, których teleomorfa należała do rodzaju Leptosphaeria, powinny być zaklasyfikowane do wcześniej opisanego rodzaju Plenodomus, a nie Phoma. Wykonane wkrótce przez Gruyter i wsp. (2009) oraz Aveskamp i wsp. (2010) badania molekularne dotyczące analiz DNA gatunków w obrębie sekcji wskazały na niejednorodność filogenetyczną gatunków w sekcjach Phoma.

Wyniki badań filogenetycznych (Aveskamp i wsp. 2010; Gruyter i wsp. 2010, 2012) wykazały, że gatunki typowe wszystkich (9) sekcji rodzaju Phoma należały do rzędu Pleosporales. W tym gatunki typowe pięciu sekcji, a mianowicie: Phoma, Phyllostictoides, Sclerophomella, Macrospora i Peyronellaea były pokrewne do gatunków rodziny Didymellaceae. Z kolei gatunek typowy sekcji Paraphoma, tj. Phoma radicina oraz Phoma heteromorphospora, typowy dla sekcji Heterospora, były pokrewne odpowiednio do gatunków w rodzinach: Phaeosphaeriaceae i Leptosphaeriaceae. Na podstawie właściwości filogenetycznych i cech morfologicznych opisano spośród gatunków zaliczonych przez Boerema (1997) do 9 sekcji rodzaju Phoma nowe rodzaje albo dla wcześniej znanych rodzajów przywrócono ich nazwy. I tak np. nowe rodzaje to: Boeremia, Heterospora, Subplenodomus, a nazwy przywrócone wcześniej opisanym rodzajom to Paraphoma, Peyronellaea, Plenodomus. Gatunki nowych i przywróconych nazw rodzajów w ogólności nie pokrywają się $\mathrm{z}$ ich wcześniejszą przynależnością do odpowiednich sekcji (Gruyter 2012). Liczba rodzajów wyłonionych obecnie $\mathrm{z}$ Phoma przewyższa liczbę opisanych sekcji przez Boerema i wsp. (2004). Aktualnie trwają badania taksonomiczne nie tylko kompleksu gatunków Phoma, ale i pokrewnych rodzajów, jak: Pyrenochaeta, Ascochyta, Coniothyrium, Stagonospora. Wobec zaistniałej sytuacji rodzaj Phoma opisany w 10. wydaniu „Dictionary of the Fungi” (Kirk i wsp. 2008), powinien, przynajmniej tymczasowo, być traktowany jako sensu lato, ponieważ obejmuje grupę 10 różnych rodzajów, 4 znanych już wcześniej oraz 5 nowych (Aveskamp i wsp. 2010; Gruyter i wsp. 2012).

Zgodnie $\mathrm{z}$ zasadą jednej nazwy dla tego samego gatunku grzyba, obowiązującą od 1 stycznia 2012 roku (Norvell 2011), bez względu na liczbę jego postaci morfologicznych (morf), wśród rodzajów pokrewnych wyłonio- 
nych obecnie $\mathrm{z}$ Phoma znajdują się nie tylko nazwy pochodzące od stadium konidialnego, ale również płciowego, tj. Leptosphaeria i Paraleptosphaeria.

W związku z zasadą jednej nazwy mykologowie, specjaliści danej grupy grzybów, przygotowują listę taksonów na różnym poziomie, w tym przede wszystkim nazw rodzajów, do zaakceptowania lub odrzucenia. Lista nazw powinna być gotowa do zatwierdzenia przez Międzynarodowy Kongres Botaniczny w sierpniu 2017 roku (Kirk i wsp. 2013).

Wszystkie opisane ostatnio rodzaje pokrewne Phoma w trakcie rozmnażania bezpłciowego cechują się takim samym typem konidiogenezy. Jest to konidiogeneza blastyczna polegająca na wytwarzaniu konidiów enteroblastycznie, w jednym punkcie, na wierzchołku komórki konidiotwórczej niezmieniającej swojej długości, nazywanej fialidą. Fialidy rozwijają się $\mathrm{z}$ wewnętrznej warstwy ściany piknidium, wyściełając ją naokoło. Fialidy są hialinowe, małe, cylindryczne, buteleczkowate, kuliste do beczułkowatych albo ampułowate (Marcinkowska 2003).

Autorzy opisanych rodzajów z Phoma sensu lato wyznaczyli dla nich gatunki typowe zgodnie z zasadami Międzynarodowego Kodeksu Nomenklatury glonów, grzybów i roślin (Norvell 2011). Dla rodzaju Phoma Saccardo (1880) gatunkiem tym pozostał $P$. herbarum Westendorp, opisany przez Boerema w 1964 roku. Dla pozostałych rodzajów gatunki typowe podane są przy ich charakterystyce.

Nadal do oznaczania rodzajów pokrewnych Phoma wykorzystuje się niektóre cechy morfologiczne (Marcinkowska 2003) z uwzględnieniem ich filogenezy.

Klucz do rodzajów Phoma sensu lato opracowany przez autora na podstawie literatury $\mathrm{z}$ uwzględnieniem cech morfologicznych obserwowanych w kulturach aksenicznych (in vitro) oraz na roślinie (in vivo).

1. Konidia jednokomórkowe, grzyby zwykle nie tworzą chlamydospor. . .2

1'. Konidia u tego samego gatunku jedno-, jedno-

i dwukomórkowe albo dwu- i trzy komórkowe, grzyby tworzą lub nie tworzą chlamydospor................8

2. W konidiach brak gutuli (krople thuszczowe).... Phoma

2'. Konidia mają gutule, choć nie zawsze wszystkie .........3

3. Ściany piknidiów grube, z zewnątrz brunatne lub czarne, pokryte lub nie różnymi szczecinkami............4

3'. Piknidia o ścianach miodowych, cienkich, ich ujścia otoczone brodawkami. Konidia elipsoidalne, prawie cylindryczne lub prawie sierpowate, z gutulami...............................Setophoma

4. Ściany piknidiów grube (2-8 warstwowe) z zewnątrz brunatne, pokryte grubymi szczecinkami lub gęstymi „,włoskami” albo gładkie. Konidia $\mathrm{z}$ gutulami Paraphoma

4'. Ściany piknidiów prawie czarne, gładkie, nieliczne konidia mają gutule

5. Piknidia tworza sie obficie 6

5'. Piknidia tworzą się rzadko, ich ściany są skleroplektenchymatyczne. Stadium płciowe to worki z 35 przegrodowymi zarodnikami workowymi, które są hialinowe, żółte lub brunatne. Paraleptosphaeria
6. Ściany piknidiów początkowo pseudoparenchymatyczne, z czasem skleroplektenchymatyczne. Zarodniki workowe 3-7 przegrodowe jasnożółte lub brunatne Plenodomus

6'. Ściany piknidiów inaczej zbudowane. 7

7. Ściany piknidiów zazwyczaj pseudoparenchymatyczne. Brak stadium płciowego. Czasami mogą tworzyć się chlamydospory pojedyncze w łańcuszku lub diktiochlamydospory...... Subplenodomus

7’. Ściany piknidiów zazwyczaj skleroplektenchymatyczne. Zarodniki workowe 3-przegrodowe ciemnobrunatne ..............Leptosphaeria

8. Grzyby nie tworzą chlamydospor . .9

8'. Grzyby tworzą chlamydospory jednokomórkowe jasnobrunatne i brunatne, jedno- lub wielokomórkowe (alternariopodobne), konidia u tego samego gatunku jednokomórkowe i nieliczne dwukomórkowe albo dwukomórkowe, z centralnie umieszczoną przegrodą poprzeczną, przy której wcięcie jest lub go brak, u niektórych gatunków występują 2 lub 3 przegrody. Peyronellaea

9. Konidia u tego samego gatunku jednokomórkowe i nieliczne dwukomórkowe, posiadają gutule Boeremia

9'. Konidia u tego samego gatunku jednokomórkowe małe (mikrokonidia) oraz duże (makrokonidia) jedno, dwu- i trzykomórkowe, z gutulami lub bez nich.

Heterospora

\section{Charakterystyka rodzajów:}

\section{Rodzaj: Phoma Saccardo}

Konidia są jednokomórkowe, hialinowe, cylindryczne, elipsoidalne. Piknidia, zwykle cienkościenne, kuliste, jasno- do ciemnobrunatnych, zagłębione częściowo w substracie, występują zazwyczaj pojedynczo. Stadium płciowe jest pokrewne rodzinie Didymellaceae.

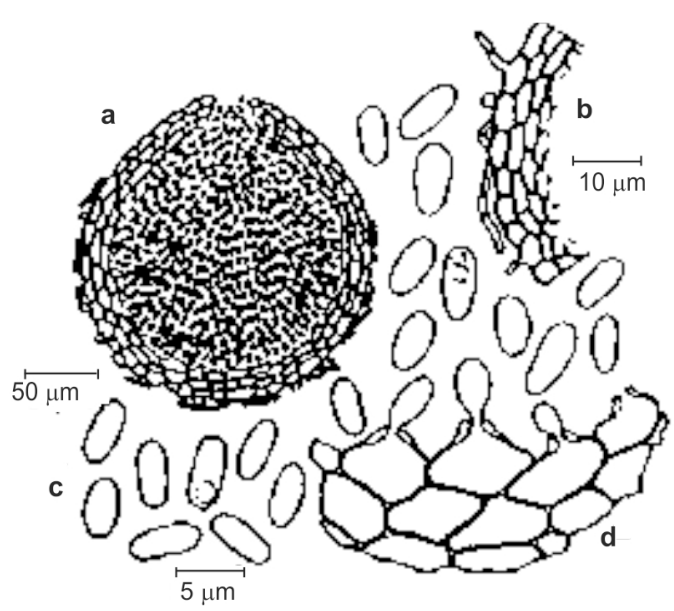

Rys. 1. Phoma herbarum: a - przekrój przez piknidium, b-przekrój fragmentu ściany piknidium, c - konidia, d - fragment ściany piknidium z komórkami konidiotwórczymi (Morgan-Jones 1988)

Fig. 1. Phoma herbarum: a - vertical section of pycnidium, bvertical section of part of pycnidial wall, $\mathrm{c}-$ conidia, $\mathrm{d}-$ part of pycnidial wall with conidiogenous cells (Morgan-Jones 1988) 
Phoma herbarum Westend, saprotrof, gatunek typowy rodzaju (Boerema 1964) (rys. 1).

Phoma medicaginis var. medicaginis Malbr. et Roum., powoduje plamistość zgorzelową lucerny, poraża liście, pędy, strąki i nasiona. Występuje w rejonach uprawy lucerny. W Polsce występuje, ale nie ma znaczenia gospodarczego.

Phoma nebulosa (Pers.) Mont., poraża pędy pokrzywy. Gatunek jest pospolity w Polsce.

Rodzaj: Boeremia Aveskamp, Gruyter et Verkley, gen. nov. MycoBank MB515621

Konidia sa hialinowe, od elipsoidalnych do prawie elipsoidalnych lub prawie kulistych albo alantoidalnych, cienkościenne, gładkie, z kilkoma małymi gutulami. Sa one najczęściej jednokomórkowe, ale również tworzą się konidia nieco większe $\mathrm{z} 1$ lub 2 przegrodami. Piknidia mają różny kształt i wielkość, zazwyczaj są kuliste do prawie kulistych, gładkie lub pokryte kilkoma krótkimi strzępkami. Konidiomy te tworzą się na pożywce lub są w niej zagłębione, występują pojedynczo lub w grupach. $\mathrm{W}$ piknidium mogą być $1-2$, a nawet 3 pory, które są wyniesione lub nie na brodawkę. Ściany piknidium zbudowane z 2-8 warstw komórek pseudoparenchymatycznych, przy czym zewnętrzne 1-3 są brunatne. Chlamydospory nie tworzą się. Stadium płciowe (teleomorfa) należy do rodziny Didymellaceae. Owocniki tego stadium (pseudotecja) prawie kuliste notowane in vivo tylko dla jednego gatunku. Worki sa cylindryczne lub prawie maczugowate, a zarodniki workowe elipsoidalne $\mathrm{z}$ jedna przegrodą (Gruyter i wsp. 2009; Aveskamp i wsp. 2010).

Gruyter i wsp. (2002, 2009) oraz Aveskamp i wsp. (2010) opisali 15 gatunków patogenów roślin należących do rodzaju Boeremia. Spośród nich w Polsce występują następujące:

Boeremia exigua (Desm.) Aveskamp, Gruyter et Verkley, gatunek typowy rodzaju, syn. Phoma exigua Desm. var. exigua, sprawca zgorzeli siewek oraz plamistości liści i pędów różnych gatunków roślin. Słaby patogen, notowany powszechnie.

Boeremia hedericola (Durieu et Mont.) Aveskamp, Gruyter et Verkley, com. nov. MycoBank MB515634, syn. Phoma hedericola (Durieu et Mont.) Boerema, powoduje plamistość liści bluszczu (Hedera helix). W Polsce grzyb występuje powszechnie.

Boeremia foveata (Foister) Aveskamp, Gruyter et Verkley, com. nov. MycoBank MB515653, (bas. - Phoma foveata Foister), poraża bulwy ziemniaka, zwłaszcza w przechowalni, wywołując chorobe zwaną w Europie gangreną (rys. 2 A).

Boeremia diversispora (Bubak) Aveskamp, Gruyter et Verkley, syn. Phoma diversispora Bubak, jest sprawcą plamistości fasoli na liściach, pędach i strąkach w rejonach uprawy fasoli. Występuje w Polsce, ale patogen nie ma większego znaczenia gospodarczego.

Boeremia lycopersici (Cooke) Aveskamp, Gruyter et Verkley, com. nov. MycoBank MB515636, (bas. - Phoma lycopersici Cooke, teleomorfa: Didymella lycopersici Kleb.), powoduje zgorzel podstawy łodyg i brunatna zgniliznę owoców pomidora (rys. 2 B). W Polsce ważny patogen.
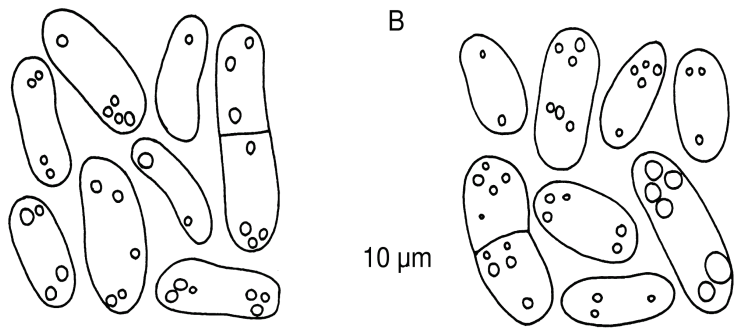

Rys. 2. Konidia: A - Boeremia foveata, B - Boeremia lycopersici (Gruyter i wsp. 2002)

Fig. 2. Conidia: A - Boeremia foveata, B - Boeremia lycopersici (Gruyter et al. 2002)

Rodzaj: Heterospora (Boerema, Gruyter et Noordeloos) Gruyter, Verkley et Crous stat. nov. MycoBank MB564701

Konidia są hialinowe, zawsze dimorficzne na roślinach, zaś in vitro tworzą się zazwyczaj jednokomórkowe, małe, prawie cylindryczne lub elipsoidalne $\mathrm{z}$ lub bez gutuli, ale mogą być znacznie większe, 1-2 przegrodowe z licznymi

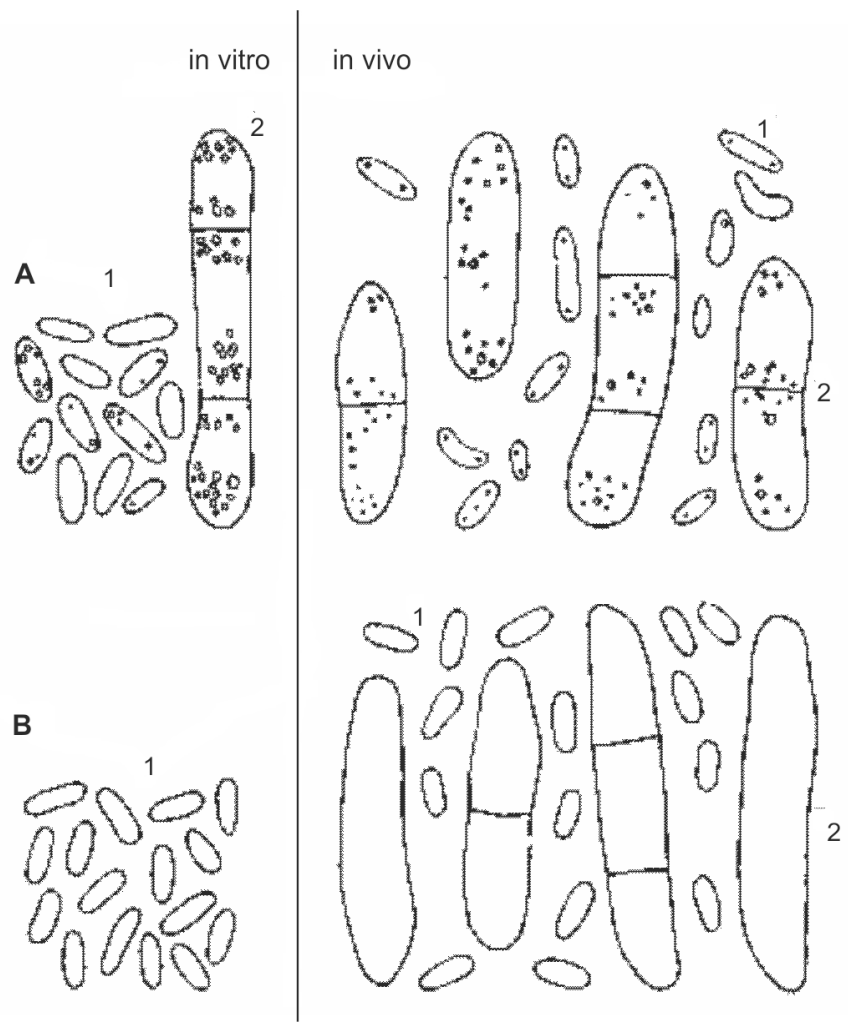

Rys. 3. A - Heterospora chenopodii, B - Heterospora dimorphospora: 1 - mikrokonidia, 2 - makrokonidia (Boerema i wsp. 1997)

Fig. 3. A - Heterospora chenopodii, B - Heterospora dimorphospora: 1 - microconidia, 2 - macroconidia (Boerema et al. 1997)

gutulami, cylindryczne lub elipsoidalne albo o kształcie niezbyt regularnym. Piknidia są kuliste do prawie kulistych, gładkie lub pokryte kilkoma krótkimi strzęp- 
kami. Tworzą się one na pożywce lub są w niej zagłębione, występują pojedynczo lub w grupach. W piknidium jest jedna, a nawet 3 pory wyniesione na brodawkę. Ściany piknidium zbudowane z 4-10 warstw komórek pseudoparenchymatycznych, przy czym zewnętrzne 1-3 są brunatne. W kulturach tworzą się też małe piknidia nazywane mikropiknidiami. Chlamydospor brak. Stadium płciowe w rodzinie Leptosphaeriaceae (Gruyter i wsp. 2009).

Opisano 2 gatunki, które są patogenami roślin.

Heterospora chenopodii (Westend.) Gruyter, Aveskamp et Verkley, gatunek typowy rodzaju, com. nov. MycoBank MB564702, syn. Phoma heteromorphospora Aa et Kesteren, izolowany z plam na liściach Chenopodium album (rys. $3 \mathrm{~A}$ ).

Heterospora dimorphospora (Speg.) Gruyter, Aveskamp et Verkley, com. nov. MycoBank MB564703, syn. Phoma dimorphospora (Speg.) Aa et Kesteren, izolowany z plam na łodygach, rzadziej z liści innych niż Ch. album gatunków rodzaju Chenopodium (rys. 3 B).

\section{Rodzaj: Leptosphaeria Ces. et De Not.}

Stadium bezpłciowe w formie dużych ciemnobrunatnych do czarnych piknidiów tworzy się powszechnie. Ściany piknidiów są grube, zwykle od początku powstawania konidiów skleroplektenchymatyczne. Konidia są hialinowe, zazwyczaj jednokomórkowe, elipsoidalne do prawie cylindrycznych. Stadium płciowe to owocniki pseudotecja, a w nich worki z zarodnikami workowymi, które są 3-przegrodowe, ciemnobrunatne (Aveskamp i wsp. 2010). Gatunki tego rodzaju są nekrotrofami.

Leptosphaeria doliolum (Pers.: Fr.) Ces. et De Not., (bas. Sphaeria doliolum Pers., syn. Phoma acuta), gatunek typowy rodzaju, izolowany najczęściej z łodyg pokrzywy, floksa (Gruyter 2012).

Leptosphaeria sydowii (Boerema, Kesteren et Loer.) Gruyter, Aveskamp et Verkley, com. nov. MycoBank MB564717, (bas. Phoma sydowii Boerema, Kesteren et Loer.), izolowany z obumarłych łodyg starca.

Rodzaj: Paraleptosphaeria Gruyter, Verkley et Crous gen. nov. MycoBank MB564720

Stadium bezpłciowe (piknidia) tworzy się rzadko. Ściany piknidiów są skleroplektenchymatyczne. Konidia są hialinowe, bez przegród, owalne do elipsoidalnych. Stadium płciowe to pseudotecja prawie kuliste, występują pojedynczo lub w grupach, mają grube ściany pseudoparenchymatyczne do skleroplektenchymatycznych. Worki są bitunikowe, fissitunikowe, szerokoelipsoidalne poprzedzielane nibywstawkami. Zarodniki workowe są szerokowrzecionowate, podzielone 3-5 przegrodami poprzecznymi, hialinowe do żółtobrunatnych (Gruyter 2012). Gatunki tego rodzaju są nekrotrofami.

Paraleptosphaeria nitschkei (Rehm.exG.Winter) Gruyter, Aveskamp et Verkley, com. nov. MycoBank MB564723, (bas. Leptosphaeria nitschkei Rehm. ex G. Winter), gatunek typowy rodzaju, izolowany z Asteraceae.

\section{Rodzaj: Paraphoma Morgan-Jones et J.F. White}

Konidia są hialinowe, elipsoidalne, jednokomórkowe, gładkie, z gutulami. Piknidia są brunatne do ciemno- brunatnych, kuliste lub prawie kuliste, z krótką szyjką, pokryte jasnobrunatnymi lub prawie hialinowymi szczecinkami, choć czasami są gładkie. Szczecinki są proste lub lekko wygięte, gładkie lub pokryte brodawkami, o grubych ścianach, kilkukomórkowe, jasnobrunatne. Piknidia występują pojedynczo lub zebrane są w grupy, na powierzchni lub częściowo zanurzone w pożywce. Ściany piknidiów są grube, zewnętrzna 2-warstwowa, ciemnobrunatna, wewnętrzna złożona z 4-5 warstw prawie hialinowych do jasnobrunatnych pseudoparenchymatycznych komórek. Morfa płciowa pokrewna jest rodzinie Phaeosphaeriaceae (Gruyter i wsp. 2010).

Gruyter i wsp. (2010) opisali 3 gatunki:

Paraphoma radicina (McAlpine) Morgan-Jones et J.F. White, gatunek typowy rodzaju, syn. Phoma radicina (McAlpine) Boerema, izolowany $\mathrm{z}$ korzeni różnych gatunków roślin, najczęściej drzew owocowych, ale i pomidora (rys. 4). Występuje w Europie, najczęściej w Niemczech i Holandii, a także w Australii i USA.

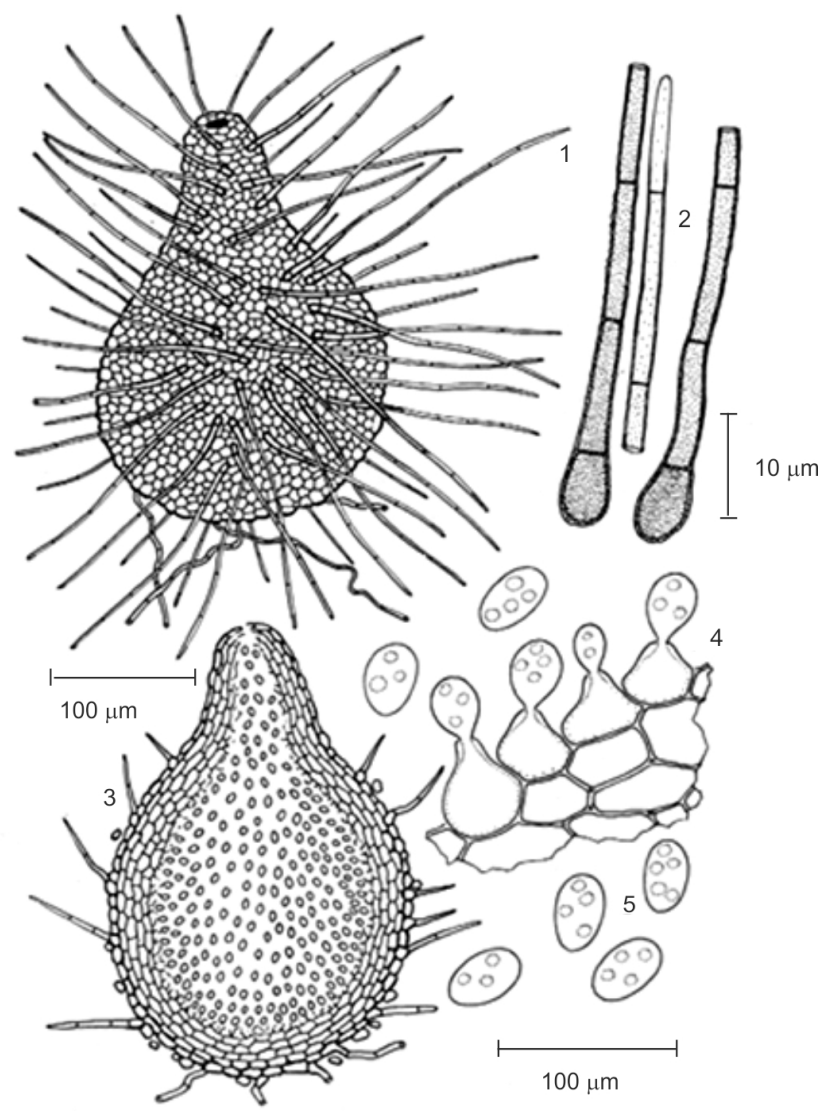

Rys. 4. Paraphoma radicina: 1 - piknidium pokryte szczecinkami, 2 - szczecinki, 3 - przekrój przez piknidium, 4 komórki konidiotwórcze, 5 - konidia (Morgan-Jones i White 1983)

Fig. 4. Paraphoma radicina: 1 - pycnidium with setae scatered over its wall, 2 - setae, 3 - vertical section of pycnidium, 4 - conidiogenous cells, 5 - conidia (Morgan-Jones and White 1983)

Paraphoma fimeti (Brunaud) Gruyter, Aveskamp et Verkley, syn. Phoma fimeti Brunaud, izolowany z gleby oraz z pędów jałowca. Notowany w Europie. 
Paraphoma chrysanthemicola (Hollos) Gruyter, Aveskamp et Verkley, syn. Phoma chrysanthemicola Hollos, poraża pędy i korzenie złocienia ogrodowego w różnych krajach Europy.

Rodzaj: Peyronellaea Goid. ex Togliani, emend. Aveskamp, Gruyter et Verkley

Konidia są cienkościenne, gładkie, jednokomórkowe, ale i dwukomórkowe lub 2-3 komórkowe, cylindryczne lub elipsoidalne, w starszych kulturach mogą się zabarwić. Piknidia są kuliste lub prawie kuliste z ujściem. Tworzą się one na powierzchni lub są zanurzone w pożywce, występują pojedynczo lub w grupach. Ściany piknidiów zbudowane z 2-8 warstw komórek pseudoparenchymatycznych, z których 1-3 zewnętrzne są brunatne lub oliwkowe. Chlamydospory występują powszechnie. Jednokomórkowe chlamydospory tworzą się często bardzo obficie w i na agarze oraz w grzybni powietrznej. Są one śródstrzępkowe, kuliste, jasnobrunatne, brunatne lub oliwkowe. Chlamydospory wielokomórkowe, szczególnie alternariopodobne są brunatne lub oliwkowe. Tworzą się one śródstrzępkowo lub na końcach strzępek, często połączone w łańcuszki. Jedynie dla paru gatunków znana jest morfa płciowa w formie pseudotecjów charakterystycznych dla rodzaju Didymella Saccardo. Pseudotecja są prawie kuliste, z cylindrycznymi lub maczugowatymi workami, zawsze z ośmioma dwukomórkowymi, o większej górnej komórce, elipsoidalnymi zarodnikami workowymi (Aveskamp i wsp. 2010).

Peyronellaea glomerata (Corda) Goid. ex Togliani, gatunek typowy rodzaju, syn. Phoma glomerata (Cda) Wollen. et Hoch. Jest to saprotrof, czasami słaby patogen, występuje na korzeniach siewek roślin jednorocznych i wieloletnich, może powodować plamistość liści i owoców różnych gatunków roślin. Gatunek pospolity w Polsce i Europie (rys. 5 A).

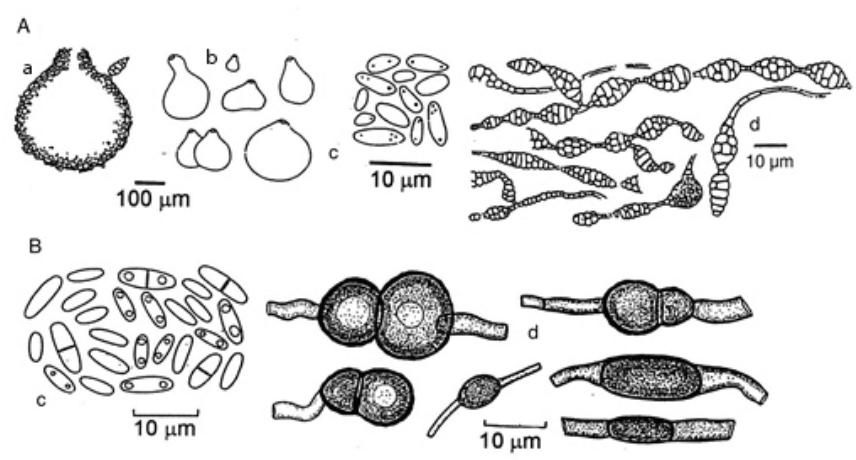

Rys. 5. A - Peyronellaea glomerata; B - Peyronellaea pinodella: a - przekrój przez piknidium, $\mathrm{b}$ - piknidia, widok z boku, c - konidia, d - chlamidospory (A - Boerema 1993, B Punithalingham i Gibson 1976)

Fig. 5. A - Peyronellaea glomerata; B - Peyronellaea pinodella: $\mathrm{a}$ - vertical section of pycnidium, $\mathrm{b}$ - pycnidia, side view, c - conidia, d - chlamydospores (A - Boerema 1993, B Punithalingham and Gibson 1976)

Peyronellaea pinodella (L.K. Jones). Aveskamp, Gruyter et Verkley, syn. Phoma pinodella (L.K. Jones) Morgan-Jones et Burch, jest sprawcą zgorzeli podstawy łodyg i szyjki korzeniowej grochu (rys. 5 B). Gatunek jest ważny gospodarczo w rejonach uprawy grochu na świecie. W Polsce występuje powszechnie i powoduje straty w plonie grochu cukrowego oraz uprawianego na suche nasiona.

Peyronellaea pinodes (Berk. et Bloxam.) Aveskamp, Gruyter et Verkley, syn. Ascochyta pinodes L.K. Jones, [teleomorfa: Didymella pinodes (Berk. et Bloxam.) Petr.], powoduje zgorzelową plamistość grochu, powszechnie występującą i ważną gospodarczo chorobę na Pisum sativum, podobnie jak ww. gatunek.

\section{Rodzaj: Plenodomus Preuss}

Konidia są hialinowe, jednokomórkowe, elipsoidalne do prawie cylindrycznych (Boerema i wsp. 1994; Torres i wsp. 2005; Gruyter i wsp. 2012). Piknidia zazwyczaj są prawie kuliste lub flaszkowate, o szerokiej podstawie, dojrzałe mają wyraźną poroidalną brodawkę lub brodawki, które mogą wydłużać się w szyję. Piknidia są przeważnie czarne, dosyć duże. Ich ściany są grube, początkowo pseudoparenchymatyczne, następnie skleroplektenchymatyczne. Stadium płciowe to owocniki pseudotecja, które są prawie kuliste, o grubych ścianach, występują pojedynczo. W pseudotecjach są bitunikowe fissitunikowe, elipsoidalne worki poprzedzielane nibywstawkami. Zarodniki workowe podzielone 3-7 przegrodami poprzecznymi, są jasnożółte do brunatnych.

Plenodomus rabenhorsti Preuss, syn. Plenodomus lingam (Tode: Fr.) Hohn., gatunek typowy rodzaju, [syn. Phoma lingam (Tode: Fr.) Desm.]. Jest sprawcą suchej zgnilizny kapustnych, ważnej gospodarczo choroby w Polsce, zwłaszcza na rzepaku (rys. 6).

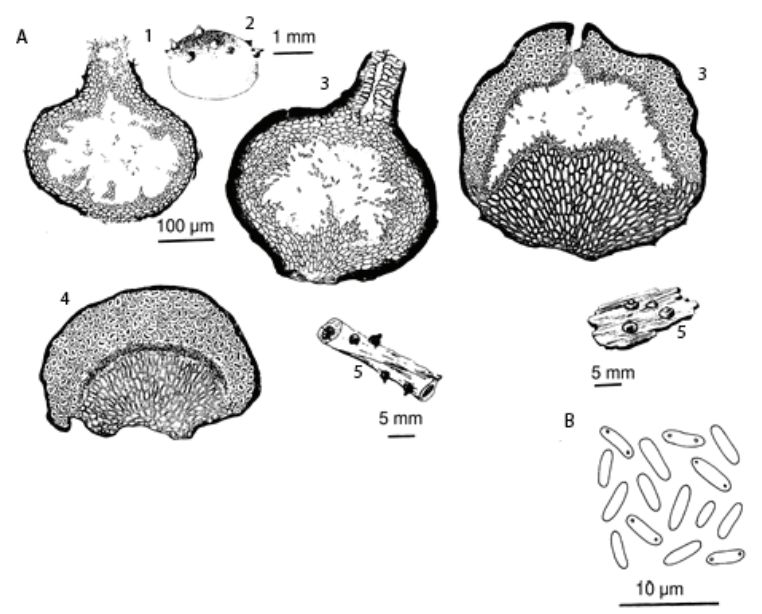

Rys. 6. Plenodomus lingam: A - przekroje przez różnego typu piknidia $\mathrm{i}$ ich występowanie na organach kapusty: 1 piknidium cienkościenne, 2 - piknidia cienkościenne na porażonym nasieniu, 3 - piknidia grubościenne, 4 piknosklerocjum, 5 - piknidia grubościenne na starym obumarłym pędzie po przezimowaniu; B - konidia (Boerema i wsp. 1994)

Fig. 6. Plenodomus lingam: A - vertical sections of its pycnidial types on cabbage: 1 - thin-walled pycnidium, 2 - thinwalled pycnidia on seed in association with disease symptoms, 3 - thick-walled pycnidia, 4 - pycnosclerotium, 5 - thick-walled pycnidia on old dead stems found next season; B - conidia (Boerema et al. 1994) 
Plenodomus biglobosus (Shoem. et H.Brun) Gruyter, Aveskamp et Verkley comb. nov. MycoBank MB564727, (bas.: Leptosphaeria biglobosa Shoem. et H. Brun), wywołuje podobnie jak Plenodomus lingam suchą zgniliznę kapustnych. Ten gatunek jest w Polsce częściej notowany niż ww.

\section{Rodzaj: Setophoma Gruyter, Aveskamp et Verkley}

Konidia są jednokomórkowe, hialinowe, elipsoidalne, prawie cylindryczne lub prawie sierpowate i posiadają gutule (Gruyter i wsp. 2010). Piknidia o ścianach zbudowanych z komórek pseudoparenchymatycznych są miodowe do oliwkowobrunatnych. Są one kuliste lub prawie kuliste, pokryte szczecinkami, otoczone brodawkami przy ujściu. Piknidia występują pojedynczo lub zebrane są w grupy umiejscowione na powierzchni lub są zanurzone w agarze. Opisane zostały 2 gatunki patogeniczne dla roślin.

Setophoma terrestris (H.N. Hansen) Gruyter, Aveskamp et Verkley, [syn. Pyrenochaeta terrestris (H.N. Hansen) Gorenz, J.C. Walker et Larson], gatunek typowy rodzaju, jest sprawcą różowej zgnilizny korzeni cebuli i pora, choroby powszechnie występującej w naszym kraju, zwłaszcza na porach.

Rodzaj: Subplenodomus Gruyter, Verkley et Crous gen. nov. MycoBank MB564769
Konidia są jednokomórkowe, hialinowe, elipsoidalne do cylindrycznych. Piknidia są kuliste, czasami z brodawką lub wydłużoną szyjką, występują pojedynczo albo w grupach. Ściany piknidium zazwyczaj cienkie, pseudoparenchymatyczne, podobne do tych u rodzaju Phoma, chociaż z czasem mogą stać się grube, skleroplektenchymatyczne. Czasami tworzą się chlamydospory. Są one oliwkowe, jednokomórkowe powstające w łańcuszkach lub jako wielokomórkowe diktiochlamydospory. Niekiedy tworzą się nawet pseudosklerocja (Gruyter 2012). Gatunki tego rodzaju to patogeny roślin oraz nekrotrofy.

Subplenodomus violicola (P. Syd.) Gruyter, Aveskamp et Verkley com. nov. MycoBank MB564774, (bas. Phoma violicola P. Syd.), gatunek typowy rodzaju, izolowany $\mathrm{z}$ plam na liściach Viola tricolor.

Subplenodomus apiicola (Kleb.) Gruyter, Aveskamp et Verkley com. nov. MycoBank MB564770, (bas. Phoma apiicola Kleb.), gatunek izolowany $\mathrm{z}$ podstawy łodygi i bulwy korzeniowej selera. Pospolity w Europie, pewnie występuje też w Polsce.

Badania sfinansowane były przez Narodowe Centrum Nauki w ramach grantu N N310 722240, natomiast koszty publikacji pokryte zostały ze środków Samodzielnego Zakładu Fitopatologii Szkoły Głównej Gospodarstwa Wiejskiego w Warszawie.

\section{Literatura / References}

Aa H.A. van der, Boerema G.H., Gruyter J. de 2000. Contribution towards a monograph of Phoma (Coelomycetes) - VI 1. Section Phyllostictoides: Characteristics and nomenclature of its type species Phoma exigua. Persoonia 17: 435-456.

Aveskamp M.M., Gruyter J. de, Woundenberg J.H.C., Verkley G.J.M., Crous P.W. 2010. Highlights of the Didymellaceae: A polyphasic approach to characterize Phoma and related pleosporalen genera. Studies in Mycology 65: 1-60.

Boerema G.H. 1964. Phoma herbarum Westend., the type species of the form-genus Phoma Sacc. Persoonia 3: 9-16.

Boerema G.H. 1993. Contribution towards a monograph of Phoma (Coelomycetes) - II. Section Peyronellaea. Persoonia 15: $197-221$.

Boerema G.H. 1997. Contribution towards a monograph of Phoma (Coelomycetes) - V. Subdivision of the genus in sections. Mycotaxon 64: 321-333.

Boerema G.H., Dorenbosch M.M.J., Loerakker W.M. 1981. Notes on Phoma. Transactions of the British Mycological Society 77: 61-74.

Boerema G.H., Gruyter J. de, van Kesteren H.A. 1994. Contributions towards a monograph of Phoma (Coelomycetes) - III 1. Section Plenomodus: Taxa often with a Leptosphaeria telemorph. Persoonia 15: 431-487.

Boerema G.H., Gruyter J. de, Noordeloos M.E. 1997. Contributions towards a monograph of Phoma (Coelomycetes) - IV. Section Heterospora: Taxa with large sized conidial dimorphs, in vivo sometimes as Stagonosporopsis synanamorphs. Persoonia 16: $335-371$.

Boerema G.H., Gruyter J. de, Noordeloos M.E., et Hamers M.E.C. 2004. Phoma Identification Manual. Differentation of Specific and Infra-Specific Taxa in Culture. CABI Publishing, Wallingford, 448 pp.

Gruyter J. de 2012. Revised taxonomy of Phoma and allied genera. PhD thesis. Wageningen University, Wageningen, NL, $181 \mathrm{pp}$.

Gruyter J. de, Aveskamp M.M., Woundenberg J.H.C., Verkley G.J.M., Groenewald J.Z., Crous P.W. 2009. Molecular phylogeny of Phoma and allied anamorph genera. Towards a reclassification of the Phoma complex. Mycological Research 30: 1-12.

Gruyter J. de, Boerema G.H. 2002. Contributions towards a monograph of Phoma (Coelomycetes) - VIII. Section Paraphoma: Taxa with setose pycnidia. Persoonia 17: 541-561.

Gruyter J. de, Boerema G.H., Aa H.A. van der 2002. Contributions towards a monograph of Phoma (Coelomycetes) - VI 2. Section Phyllostictoides: Outline of its taxa. Persoonia 18: 1-53.

Gruyter J. de, Woundenberg J.H.C., Aveskamp M.M., Verkley G.J.M., Groenewald J.Z., Crous P.W. 2010. Systematic reappraisal of species in Phoma section Paraphoma, Pyrenochaeta and Pleurophoma. Mycologia 102: 1066-1081.

Gruyter J. de, Woundenberg J.H.C., Aveskamp M.M., Verkley G.J.M., Groenewald J.Z., Crous P.W. 2012. Redisposition of Phoma-like anamorphs in Pleosporales. Studies in Mycology 75: 1-36.

Kirk P.M., Cannon P.F., David J.C., Stalpers J.A. 2001. Ainsworth and Bisby's Dictionary of the Fungi. Ninth Edition. CAB International, Wallingford, $655 \mathrm{pp}$

Kirk P.M., Cannon P.F., Minter D.W., Stalpers J.A. 2008. Ainsworth and Bisby's Dictionary of the Fungi. Tenth Edition. CAB International, Wallingford, $771 \mathrm{pp}$. 
Kirk P.M., Stalpers J.A., Braun U., Crous P.W., Hansen K., Hawksworth D.L., Hyde K.D., Lücking R., Lumbsch T.H., Rossman A.Y., Seifert K.A., Stadler M. 2013. A without-prejudice list of generic names of fungi for protection under the International Code of Nomenclature for algae, fungi, and plants. IMA Fungus 4: 381-443.

Marcinkowska J. 2003. Oznaczanie rodzajów grzybów ważnych w patologii roślin. Fundacja - Rozwój SGGW, Warszawa, 328 ss.

Morgan-Jones G. 1988. Studies in the genus Phoma XV. Concerning Phoma herbarum, the type species, a widespread saprophyte. Mycotaxon 33: 81-91.

Morgan-Jones G., White J.F. 1983. Studies in the genus Phoma III. Paraphoma, a new genus to accommodate Phoma radicina. Mycotaxon 18: 57-65.

Mułenko W., Majewski T., Ruszkiewicz-Michalska M. 2008. A preliminary checklist of micromycetes in Poland. W. Szafer Institute of Botany, P.A.S., Kraków.

Norvell L.L. 2011. Melbourne approves a new Code. Mycotaxon 116: 481-490.

Punithalingam E., Gibson I.A.S. 1976. Phoma medicaginis var. pinodella. Descriptions of Pathogenic Fungi and Bacteria. Set 52, No. 518, CMI, Kew.

Saccardo P.A. 1880. Conspectus generum fungorum italiae inferiorum nempe ad Sphaeropsideas, Melanconieas et Hyphomyceteas pertinentium, systemate sporologico dispositoru. Michelia 2: 1-38.

Torres M.S., Bergen M., Singh S., Bischoff J., Sullivan R.F., White J.F. 2005. Plenodomus morganjonesii sp. nov. and a discussion of the genus Plenodomus. Mycotaxon 93: 333-343. 